\title{
Wykorzystanie Biblii w tekście apokryficznym i kaznodziejskim na przykładzie staropolskich tłumaczeń perykopy o uzdrowieniu syna dworzanina ${ }^{1}$
}

\section{Wstęp}

Ponad 60 lat temu w kanonicznej już książce „The study of the Bible in the Middle Ages” Beryl Smalley zauważyła: „The Bible was the most studied book in the Middle Ages” (Smalley, 1978, s. xi). Dziś z całą pewnością można powiedzieć, że Pismo Święte było nie tylko najczęściej/najbardziej studiowaną, ale także niezwykle często wykorzystywaną w innych tekstach średniowiecznych księgą. Biblia, zgodnie ze stwierdzeniem Eyala Polega i Laury Wright, służyła nauce i kaznodziejstwu, prywatnej dewocji i liturgii (zob. Poleg, Light, 2013). Między innymi z tego względu była wcześnie tłumaczona na języki wernakularne.

Nie zachowało się kompletne średniowieczne tłumaczenie Biblii na język polski możemy przypuszczać, że takowe istniało, czego świadectwem jest np. Biblia królowej Zofii, z której współcześnie znamy tylko fragmenty Starego Testamentu². Takie przekonanie wzmacnia również wiedza na temat przekładów Pisma Świętego na inne języki słowiańskie, np. na język czeski: „Do naszych czasów w języku czeskim zachowało się aż 25 rękopiśmiennych pełnych przekładów biblijnych, 22 tłumaczenia Starego Testamentu, 38 Nowego Testamentu, 20 psałterzy i przeszło 60 fragmentów Biblii" (Wanicowa, 2010, s. 14; podkreślenie D.M.).

\footnotetext{
1 Artykuł powstał w ramach grantu Narodowego Centrum Nauki (projekt nr 2017/26/E/HS2/000083) „Początki języka polskiego i kultury religijnej w świetle średniowiecznych apokryfów Nowego Testamentu”, realizowanego w Instytucie Filologii Polskiej UAM.

2 Zbiorcze omówienie staropolskich przekładów Pisma św. przedstawia np. Maria Kossowska (1968) czy Rajmund Pietkiewicz (2013, 2016).
} 
Badacz średniowiecznej polszczyzny obcuje jednak wyłącznie z fragmentami Pisma Świętego. Ma on do dyspozycji nieliczne rękopisy zawierające większe partie biblijne: ewangeliarze i psałterze ${ }^{3}$, oraz rozproszone w różnego typu tekstach, np. kazaniach, apokryfach, traktatach, liczne drobne wyimki. Mariusz Leńczuk, który zebrał wszystkie rozpoznane w różnego typu tekstach fragmenty thumaczenia Nowego Testamentu na język polski ${ }^{4}$, zwrócił uwagę nie tylko na duże rozproszenie fragmentów Biblii, ale także na różną formę, w jakiej występują one w rękopisach (,ttumaczenia ciągłe, transglosacje, pojedyncze glosy do wyrazów łacińskich", Leńczuk, online; zob. także Leńczuk, 2016, s. 124). Ekscerpowane z innych tekstów wyimki są bardzo ważnym materiałem do badań tego, co możemy nazwać polskimi średniowiecznymi tłumaczeniami Biblii, a jednocześnie stanowią one podstawowe źródło wiedzy o funkcjonowaniu i wykorzystywaniu tego tekstu w polskim średniowieczu.

Istnienie tłumaczeń zarówno pojedynczych ksiąg, jak i fragmentów tekstu biblijnego w zabytkach różnego typu nie dziwi. Jak powiedziano, Pismo Święte odgrywało bardzo istotną rolę w edukacji, kaznodziejstwie, liturgii etc. Badacze zachodni zwracają uwagę na praktykę „nieciągłej” lektury tego tekstu (discontinuous reading), która „led to the cutting up of the Bible into specific, usuable parts, bound separately" (Stallybrass, 2002, s. 47).

Szczególnie istotna jest tu perspektywa przyjęta przez Margriet Hoogvliet, która zauważyła:

The Bible was a flexible text and [...] fragments, paraphrases and abridgements in the vernacular were a useful format, because they presented to the reader a text that was customized for specific reading practices that required a selective and discontinuous consultation of the Bible (Hoogvliet, 2013, s. 286).

Badaczka na podstawie materiału starofrancuskiego rozpoznała i wskazała najbardziej typowe formy funkcjonowania i obiegu tekstu biblijnego w średniowieczu, wyznaczając cztery grupy tekstów:

- charakterystyczne części Pisma św. (na przykład skróty/wypisy ze Starego Testamentu, księgi mądrościowe, Księga Psalmów);

- czytania biblijne wykorzystywane w czasie mszy w roku liturgicznym;

- opis życia i pasji Jezusa, oparty na ewangeliach;

- zbiory cytatów biblijnych z objaśnieniem/wskazówkami moralnymi (Hoogvliet, 2013, s. 287) .

Przywołanie wyników badań zachodnioeuropejskich jest w tym wypadku ważne, ponieważ procesy czy zjawiska zidentyfikowane w innym języku i w bardzo licznych

${ }^{3}$ Zabytki te stanowiły i stanowią przedmiot zainteresowania wielu badaczy i nie sposób wskazać (nie jest to też moim celem) wszystkich istotnych opracowań dotyczących tej grupy tekstów; zob. np. Kwilecka, 2003.

${ }^{4}$ Badacz szacuje: „Na stronie przygotowano transkrypcje do prawie 4000 wersetów łacińskich, co stanowi około $42 \%$ całego Nowego Testamentu" (Leńczuk, online).

${ }^{5}$ Dla porządku oraz w celu uniknięcia powtórzeń w dalszej części artykułu odnoszę się do poszczególnych grup tekstów, używając numeracji (odpowiednio 1-4), zgodnie z kolejnością zastosowaną przez M. Hoogvliet. 
tekstach wernakularnych stanowią kontekst i punkt odniesienia dla nielicznych i przez to niepozwalających na uogólnienia w interesującym mnie temacie zabytków polskich. Można sądzić, że to właśnie ze względu na duże straty w zbiorach (opisywane wielokrotnie przez badaczy) nie da się w odniesieniu do polskiego średniowiecza stwierdzić istnienia całego spektrum funkcjonowania (wykorzystywania, komentowania) tekstu biblijnego zaprezentowanego przez M. Hoogvliet. To, że zostało ono zidentyfikowane w średniowiecznych tekstach stworzonych w innym europejskim języku narodowym, pozwala przypuszczać, że i na terenie średniowiecznej Polski Biblia była wykorzystywana na bardzo różne sposoby, nie tylko takie, których świadectwo znajdujemy do dzisiaj w nielicznych rękopisach.

Do pierwszej grupy wyodrębnionej przez M. Hoogvliet należą polskojęzyczne (lub - jak w wypadku „Psałterza floriańskiego” - wielojęzyczne) psałterze („Psałterz floriański”, „Psałterz puławski”) oraz (być może) drobniejsze zabytki, jak wyjątki z ksiąg Exodus i Leviticus ze zbiorów Biblioteki Ossolieum we Wrocławiu (zob. Wydra, Rzepka, 2004, s. 75).

Grupę drugą mogłyby reprezentować nieliczne ewangeliarze (np. Ewangeliarz kanoników regularnych z Krakowa czy rękopis BN 3019 IV, zawierający kilka lekcji ewangelicznych, z zastrzeżeniem, że są to rękopisy łacińskie, w których partie w języku wernakularnym są zapisane w interliniach, nie mamy tu więc do czynienia w całości z polskimi tekstami, a raczej ze świadectwem pracy użytkowników rękopisu nad tekstem łacińskim) ${ }^{6}$.

Istnieje także grupa polskojęzycznych tekstów, nazywanych przez badaczy apokryfami czy też narracjami biblijno-apokryficznymi, które można przyporządkować do trzeciej kategorii wyodrębnionej przez badaczkę - opisów życia i pasji Jezusa opartych na ewangeliach: „Rozmyślanie przemyskie”, „Sprawa chędoga”, „Karta Rogawskiego” czy „Żywot Pana Jesu Krysta” Baltazara Opeca ${ }^{7}$

Nie da się natomiast wskazać żadnego z polskojęzycznych zabytków, który odpowiadałby ostatniej grupie wydzielonej przez M. Hoogvliet.

Francuska badaczka rozpoznała możliwe sposoby wykorzystywania tekstu biblijnego w średniowieczu, nie podniosła jednak problemu, w jaki sposób fragmenty Pisma Świętego funkcjonują pod względem kształtu językowego czy sposobu ich komentowania w tekstach z różnych grup. Wydaje się, że wraz z identyfikacją tych form powstaje pytanie, czy sposób wykorzystania Pisma Świętego w tak wyodrębnionych grupach (charakterystycznych typach funkcjonowania) jest różny, a jeśli tak - to jakie różnice

${ }^{6}$ Szczegółowe informacje o zachowanych fragmentach ewangeliarzy przedstawia Irena Kwilecka, która podsumowuje: „Nie dochował się [...] z tych czasów ani jeden pełny zbiór perykop ewangelijnych i lekcyjnych (tj. plenariusz), chociaż wtedy niewątpliwie już takie musiały istnieć" (2003, s. 50). W innym miejscu badaczka podkreśla rolę tych tekstów „,w dziejach polskich przekładów Biblii oraz w historii recepcji Pisma św. w społeczeństwie polskim" (Kwilecka, 2003, s. 90).

7 Tym oraz pozostałym staropolskim tekstom apokryficznym poświęcony jest projekt NCN „Początki języka religijnego...”, w którego ramach transliteracje i transkrypcje wszystkich zabytków zostaną udostępnione na stronie www.apocrypha.amu.edu.pl. 
można zaobserwować. Problem ten chciałabym rozważyć na materiale staropolskim. Nie jest możliwe porównanie wykorzystania tego samego fragmentu Pisma Świętego w polskich tekstach reprezentujących wszystkie typy ze względu na wspomnianą już szczątkowość zachowanego materiału. Dlatego aby odpowiedzieć na to pytanie, postanowiłam poddać analizie sposób funkcjonowania perykopy biblijnej z Ewangelii wg św. Jana o uzdrowieniu syna dworzanina ( $\mathrm{J} 4,45-54)$ w tekstach pochodzących z dwóch różnych grup wyodrębnionych przez M. Hoogvliet. W centrum uwagi celowo stawia się teksty skrajnie od siebie różne: fragment „Rozmyślania przemyskiego” (dalej: RP), największego staropolskiego apokryfu, liczącego ponad 800 kart, reprezentującego w dużej partii grupę trzecią ${ }^{8}$, oraz część tzw. Kazań augustiańskich (dalej: Kaug), dwujęzycznej adaptacji fragmentu materiałów kaznodziejskich składających się m.in. z perykopy biblijnej z komentarzami (szczegółowy opis zabytku zob. Masłej, 2017, 2020), które można przypisać do grupy drugiej.

\section{Perykopa o uzdrowieniu syna dworzanina w „Rozmyślaniu przemyskim” i ,Kazaniach augustiańskich"}

Oba analizowane teksty więcej dzieli, niż łączy, ich zestawienie jest więc nieoczywistym zabiegiem. Różni je przede wszystkim gatunek - w pierwszym wypadku mamy do czynienia z tekstem apokryficznym, wieloźródłowym ze względu na jego charakter (zob. np. Rojszczak-Robińska, 2012; Mika, Rojszczak-Robińska, 2016), w drugim z fragmentem kazania przygotowywanego do wygłoszenia. Z odmiennym gatunkiem wiąże się oczywiście różne przeznaczenie tych tekstów oraz inna ich kompozycja, co zostanie omówione w dalszej części artykułu. Teksty te różnią się także pod względem językowym: tekst w całości polskojęzyczny (RP) jest porównywany z tekstem dwujęzycznym (polsko-łacińskim), w którym oboma językami oddaje się te same treści, oba cechuje podobne bogactwo form i struktur (charakterystyka dwujęzyczności „Kazań augustiańskich" została przedstawiona w: Masłej, 2020).

Pokazując to, co różni oba teksty, nie można pominąć zagadnienia podstawy źródłowej. RP jest oparte na licznych źródłach (przede wszystkim łacińskich) ${ }^{9}$, twórczo kompilowanych przez polskiego pisarza (zob. Rojszczak-Robińska, 2012). Tekst w takim kształcie, w jakim się zachował, jest pod względem doboru źródeł i sposobu ich łączenia

8 „Rozmyślanie przemyskie” treściowo zdecydowanie wykracza poza ewangelie, lecz jego obszerna część, jak pisze I. Kwilecka, to „niemal w całości piętnastowieczny polski przekład Ewangelii z objaśnieniami i komentarzem” (2003, s. 90). Jak zauważył M. Leńczuk, „ten obszerny, a co najważniejsze dostępny zabytek języka pośród przytaczanych przez średniowiecznego mutatora fragmentów dzieł [...] skrywa w sobie tłumaczenia około 2000 wersetów NT" (2016, s. 124). Warto przypomnieć, że obszerne fragmenty RP oraz „Żywota Pana Jezu Krysta” I. Kwilecka uznaje za drugi typ thumaczenia tekstów biblijnych (tłumaczenia dla ludu) (2003, s. 129, 148).

9 Łacińskie źródła RP zostały w dużej mierze rozpoznane przez badaczy tego zabytku (zob. Dobrzeniecki 1969; RP, 1998-2004; Mazurkiewicz, 2007; Rojszczak-Robińska, 2015). O czeskim źródle RP pisała Karolina Borowiec (2015). 
dziełem polskojęzycznego pisarza. Kaug tymczasem mają - wieloźródłową, ale niepodlegającą zmianom w procesie tłumaczenia/adaptacji - bezpośrednią łacińską podstawę (zapisaną w tym samym rękopisie).

Ponadto RP, co zostało udowodnione (zob. np. Mika, 2015), jest tekstem wielowarstwowym genetycznie - zachowany zabytek jest którąś z kolei kopią, w której nie da się wskazać wszystkich zmian wprowadzonych przez kolejnych glosatorów i kopistów (lecz z całą pewnością da się stwierdzić ich obecność; zob. np. Twardzik, 1994; Mika, 2015). Kaug najpewniej nie są natomiast kopią, lecz stanowią tekst oryginalny, świadectwo pracy ich autora, kaznodziei.

Tym, co łączy te teksty i co jest dla podjętego tematu najistotniejsze, jest przynależność do przywołanego we wstępie spektrum specyficznych form, w których tekst biblijny istniał w średniowieczu, oraz wystąpienie w obu tekstach tej samej perykopy biblijnej, co jest rzadkością w polskojęzycznych i polsko-łacińskich tekstach średniowiecznych.

Dla znalezienia odpowiedzi na pytania, czy sposób wykorzystania Pisma Świętego w wyodrębnionych przez M. Hoogvliet grupach tekstów jest różny i jakiego typu różnice można wskazać, najistotniejsza wydaje się przy porównywaniu fragmentów z RP i Kaug charakterystyka miejsca perykopy biblijnej w tekście oraz sposobu jej wkomponowania w większą strukturę, a także doboru źródeł i komentowania tekstu biblijnego.

W RP perykopa z Ewangelii św. Jana pojawia się na 253 karcie tekstu i stanowi 182 jego rozdział. Jest elementem ciągu wydarzeń ewangelicznych, przejmowanych za różnymi ewangelistami; poprzedza ją przywołanie fragmentów o nauczaniu Jezusa w Galilei za św. Łukaszem i Mateuszem oraz opowieść o trudzie proroka (,żaden prorok nie jest dobrze widziany w swojej ojczyźnie”, Łk 4,24) za św. Łukaszem, po niej zaś następuje wątek uzdrowienia chromego w sadzawce przekazany za Ewangelią św. Jana. Interesująca mnie perykopa jest wprowadzona za pomocą tytułu informującego o treści rozdziału oraz o źródle, z którego została zaczerpnięta: „O tem, jako miły Jesus uzdrowił syna jednego krola. Święty Jan ewanjelista <pisze>". Wacław Twardzik dla tego rozdziału wskazuje tylko dwa źródła: Ewangelię wg św. Jana oraz rozdział 49 z „Historia scholastica” Piotra Comestora, przy czym Pismo Święte jest tu główną podstawą (zob. RP, 1998, s. 253-254). Pisarz historię biblijną zmodyfikował w zaledwie dwóch miejscach (zaznaczonych w tekście pismem pogrubionym):

I przyszedł do Kany, do wsi galilejskiej ziemie, gdy był uczynił wino z wody. A był tamo jeden krol, czusz namocniejszy po krolu tej ziemie, ktoregoż syn niemogł w Kafarneum. Ten usłysząc, iże miły Jesus przyszedł z Judei do Galileej, szedszy do niego i prosił jego, <aby przyszedł i uzdrowił syna jego>, iże już był począł umirać. Odpowiedziawszy miły Jesus i rzekł jemu: „Kiedy nie widzicie znamion a cud, nie wierzycie”. A on rzekł k niemu: „Panie miły, stępi, pirwej niżli syn moj umrze”. Miły Jesukryst rzekł k niemu: „Idzi, synci twoj jest żyw”. Wierząc on człowiek mowie miłego Jesukrysta i pojdzie. A jako już będzie schodzić ku domu, pośratną ji słudzy jego powiedając jemu, iże syn twoj jest żyw. A on ich pocznie pytać, ktorej godziny jemu odelgło. A oni jemu powiedzieli, iże wczora siodmej godziny opuściła ji zimna niemoc. Tako on poznał, iże tej godziny było, ktorej jemu rzekł miły Jesus, iże syn twoj jest żyw. I uwierzył on i dom jego wszytek (RP, 1998, s. 253).

Oba zaznaczone fragmenty, wykraczające poza tekst biblijny, służą jego wyjaśnieniu: pierwszy z nich należy do grupy bardzo popularnych objaśnień realiów biblijnych 
(zob. np. Kwilecka, 2003, s. 129; Menache, Horowitz, 1996, s. 328) i tłumaczy potencjalnie nieznaną, bo obcą odbiorcy nazwę miejscową Kana - jest to wieś. Jako że mamy do czynienia z tekstem wielowarstwowym, należy pamiętać, że geneza wyrażenia „do wsi galilejskie ziemie" może być różna: fragment ten mógł znajdować się w pierwszej redakcji polskiego tekstu (a zatem pochodzić od autora), mógł też - jak wiele innych glos (zob. np.: Gesner, 2011; Mika, 2015; Masłej, Mika 2020) - zostać do niego wprowadzony na etapie tworzenia którejś kopii (a zatem może pochodzić od kopisty). Z perspektywy syntaktycznej wypada zauważyć, że wyjaśnienie zostało „dosunięte” do nazwy własnej, tworząc z nim szereg składniowy (w tym wypadku dwa połączone asyndetycznie identyczne wyrażenia przyimkowe). Drugi komentarz ma źródło w „Historia scholastica" Piotra Comestora i dotyczy słowa regulus, oddanego w polszczyźnie wyrazem król. Do tekstu zostało wprowadzone wyrażeniem czusz (odpowiadającym łacińskiemu id est). Ten fragment będzie też komentowany - co zostanie szczegółowo omówione w dalszej części artykułu - w drugim z analizowanych przeze mnie tekstów.

W wypadku „Kazań augustiańskich” cała kompozycja tekstu została zaczerpnięta z tekstu łacińskiego - zasadnicze ramy tekstu (jego układ, miejsce komentarzy) są w całości przejęte przez polsko-łacińskiego glosatora. Wynika to stąd, że „Kazania augustiańskie" stanowią polsko-łacińską adaptację łacińskiego tekstu modelowego (zob. Masłej, 2020). Łaciński tekst należał do starszego typu kazań, zwanego homilia, który - jak zauważył Siegfried Wenzel - nie miał zbyt złożonej kompozycji:

It was essentially an exposition of a scriptural text, most often the pericope (the prescribed passage) of the day. After reading the biblical text, the preacher would explain it and then add some moral lesson drawn from it. In its most developed form the homily would have three parts: biblical text, literal exposition and spiritual (moral or allegorical) exegesis (Wenzel, 2005, s. 85).

Ze względu na odmienny gatunek tekstu w „Kazaniach augustiańskich” perykopa biblijna nie jest, jak w wypadku RP, elementem ciągu wydarzeń biblijnych podawanych jedno po drugim, ale stanowi - jako omawiane czytanie przeznaczone na daną niedzielę w roku liturgicznym ${ }^{10}$ - jedyny fragment $\mathrm{z}$ ewangelii w tekście. Tekst biblijny poprzedzony jest dobranym tematycznie egzemplum (opowiadającym historię uzdrowienia syna króla) oraz jego alegorycznym objaśnieniem (odnoszącym tę narrację do historii zbawienia). Po nim następuje wprowadzenie do perykopy, w którym przywołany zostaje szerszy kontekst wydarzeń biblijnych. Uzdrowienie syna dworzanina jest usytuowane w sekwencji innych zdarzeń opisanych w ewangelii i w chronologii dziejów:

In illo tempore. I w $<\mathrm{k}>$ tory się to czas działo? Rozumiej, iż ty rzeczy, o ktorych się ewanjelija toczy, działy się [a] prosto w poł roku tegoż lata pirwszego, quando Christus, przyszedszy in Iudeam, vidit filium Alphei (sic dicti Iudei) na cle siedzącego, nomine Matheum, quem vocavit, i naśladował go. Cum vero redirent [...] in Galileam, transiens per Samariam [...]. Przyszła do niego mulier Samarytanka, $\mathrm{z}$ ktorąż barzo długo się z nią rozmawiał [...].

${ }^{10} \mathrm{~W}$ wypadku perykopy o uzdrowieniu syna dworzanina z dużą pewnością można powiedzieć, że było to czytanie przeznaczone na 21 niedzielę po Zesłaniu Ducha Świętego. 
Na początku zostało przypomniane, że omawiane zdarzenia miały miejsce w pierwszym roku działalności Chrystusa po tym, jak Jezus powołał celnika Mateusza, i po spotkaniu z Samarytanką w drodze do Galilei. Dopiero wówczas zostaje przywołana perykopa o uzdrowieniu syna dworzanina, wprowadzona łacińskim zdaniem: „Sicut recitat hodiernum Evangelium Iohannis IIII ${ }^{\circ}$ : «Erat quidam regulus, cuius filius infirmabatur Capharneum»”. Fragment biblijny funkcjonuje w „Kazaniach augustiańskich” inaczej niż w RP. Ta część tekstu, w której przywołuje się tekst Ewangelii, jest zbudowana na poszczególnych wersetach lub ich fragmentach, każdorazowo uzupełnianych różnego typu komentarzami, a co za tym idzie - to właśnie fragmenty z Pisma Świętego są głównym elementem konstrukcyjnym. Tutaj, w przeciwieństwie do przywołanego ustępu z RP, każdy z fragmentów ewangelii jest komentowany, a komentarz najczęściej dotyczy więcej niż jednego elementu ${ }^{11}$. Do liczącej sobie siedem zdań perykopy odniesiono łącznie kilkanaście komentarzy. Przyjrzyjmy się sposobowi wyłożenia pierwszego zdania:

„Erat quidam regulus, cuius filius infirmabatur. Capharnaum”. I wykłada ty słowa, scilicet Chrisostomus, hic erat de genere regali. Et dictus regulus, et non rex, bo nie miał wszystkiego krolewstwa, ale jako powiada tenże doktor, scilicet Chrisostomus, iż miał w temże krolewstwie niektore państwo, jako hodie staro[w]stwo albo wojewodztwo, i rzeczon krolikiem, iż miał jakoby pirwszy urząd po krolu. Tegoż krolika syn niemogł na śmierć, a to niemocą zimnice, w Kafarneum, w tem to mieście, któreż civitas było głowne, w ktoremże był jarcybiskup, jakoby hodie Gniezno albo Cracovia.

Komentarze dotyczą trzech elementów: postaci dworzanina ( $k r o l i k a)$, choroby jego syna oraz miejsca, w którym dzieją się opisywane wydarzenia (Kafarnaum). Większość z nich służy uszczegółowieniu lub przybliżeniu odbiorcy realiów biblijnych. Mamy tu do czynienia z wyjaśnianiem m.in. potencjalnie obcych nazw własnych, podobnie jak miało to miejsce w RP, ale także z wykładnią teologiczną sensów tej perykopy ${ }^{12}$.

Pierwszy fragment tej perykopy dobrze pokazuje możliwy stopień rozbudowania objaśnień: „w Kafarneum, w tem to mieście, ktoreż civitas było głowne, w ktoremże był jarcybiskup, jakoby hodie Gniesno albo Cracovia" to odpowiednik łacińskiego fragmentu z tekstu głównego: „Capharneum, que erat civitas metropolis Galilee”. Jeden z elementów komentarza pochodzi z łacińskiego źródła (Kafarnaum było miastem głównym), a uzupełnienia wprowadzone przez polskiego autora dołączone są do różnych elementów, co powoduje skomplikowanie całej struktury. Pierwsze z dosuniętych apozycyjnie objaśnień: „w tem to mieście” dotyczy potencjalnie nieznanej nazwy własnej Kafarneum, która pojawia się w rozpoczęciu perykopy biblijnej: „Erat quidam regulus, cuius filius infirmabatur Capharnaum". Kolejne natomiast odnosi się już do komentarza

11 Taka struktura tekstu jest zaczerpnięta $\mathrm{z}$ łacińskich materiałów kaznodziejskich zapisanych w tym manuskrypcie. Aleksander Brückner o innym, w taki sam sposób skomponowanym rękopisie pisał, że jest to „postylla, t.j. obszerny wykład lekcyi ewanielicznej, wiersz za wierszem, z Glossa ordinaria i interlinearis itd." (1901, s. 180; pisownia oryginalna).

12 W „Kazaniach augustiańskich” nie wszystkie komentarze służą objaśnianiu pojedynczych słów czy zdarzeń. Niektóre z nich zawierają wyłącznie przetworzoną opowieść o danym fragmencie, niekiedy rozszerzoną w stosunku do tekstu Ewangelii i wyrażoną innymi słowami, ale niemającą charakteru objaśnień. 
zaczerpniętego ze źródła (,ktoreż civitas było głowne”), przy czym także i to wyjaśnienie składa się z dwóch elementów: literalnego objaśnienia wyrażenia ,civitas (miasto) głowne" - takie, w którym jest arcybiskup, oraz odniesienia tego do realiów ówczesnej Polski: tak jak dziś Gniezno lub Kraków.

Podobnie jak w RP jest komentowany również w „Kazaniach augustiańskich” wyraz regulus (w RP krol, w Kaug krolik), określający bohatera perykopy biblijnej. Warto przypomnieć, że jest to jeden z tematów chętnie podejmowanych w tekstach średniowiecznych. Pisała o tym na przykładzie kazania Mikołaja Wiganda Anna Zajchowska-Bołtromiuk:

Wątpliwości dotyczące „królewskości” urzędnika wzięły się stąd, że - jak zauważa kaznodzieja - Judea nie miała króla, co potwierdzają słowa Żydów stojących przed Piłatem i krzyczących „,poza Cezarem nie mamy króla”. Stąd się bierze przypuszczenie, że „ów urzędnik został wyznaczony przez cesarza, aby nadzorować Galileę, stąd też przebywał w Kafarnaum, które było stolicą tej ziemi” (Zajchowska-Bołtromiuk, 2018, s. 615-616).

Autorka wskazała też na apokryficzny charakter tego typu komentarzy, które wynikają w pewnej mierze z ciekawości średniowiecznych autorów. Fakt, że zagadnienie to zostało podjęte w obu analizowanych tu tekstach, może dodatkowo świadczyć o jego popularności:

RP: A był tamo jeden krol, czusz namocniejszy po krolu tej ziemie, ktoregoż syn niemogł w Kafarneum. Kaug: „Erat quidam regulus, cuius filius infirmabatur. Capharneum”. I wykłada ty słowa, scilicet Chrisostomus, hic erat de genere regali. Et dictus regulus, et non rex, bo nie miał wszystkiego krolewstwa, ale jako powiada tenże doktor, scilicet Chrisostomus, iż miał w temże krolewstwie niektore państwo, jako hodie staro[w]stwo albo wojewodztwo, i rzeczon krolikiem, iż miał jakoby pirwszy urząd po krolu.

Oba komentarze różnią się pod względem zarówno obszerności, jak i miejsca wprowadzenia do tekstu. W RP objaśnienie następuje bezpośrednio po elemencie wymagającym komentarza (podobnie jak w „Historia scholastica” Comestora), w Kaug pojawia się ono po całym cytacie z Pisma Świętego. Pisarz w tym krótkim fragmencie dwukrotnie wskazuje autora, od którego zaczerpnął wiedzę.

W całym tekście autor kilkakrotnie podaje źródło, z którego zaczerpnął komentarz, zawsze niedokładnie: powołuje się na Chryzostoma, Bedę czy - ogólnie - na „doktorów” (Kościoła). Równie często jednak źródła nie podaje. Najprawdopodobniej mamy tu do czynienia z typowymi dla średniowiecza działaniami, to znaczy powoływaniem się na autorytety w celach retorycznych lub przywoływaniem tekstów z pamięci. Było to charakterystyczne dla wielu autorów średniowiecznych, także dla pisarza „Rozmyślania przemyskiego”, co wielokrotnie pokazywała w swoich pracach D. Rojszczak-Robińska.

Ponadto skryba, używając dwóch języków, objaśnia szczegółowo sposób nazwania bohatera: regulus, ponieważ w przeciwieństwie do króla nie rządzi całym królestwem (podobnie jak w RP: król, czyli „najmocniejszy po krolu”). Warto zwrócić uwagę, że w Kaug komentarz dotyczy doboru słów zarówno po łacinie (et dictus regulus et non rex), jak i po polsku (i nazwan krolikiem). Interesujący jest polski wyraz, który został 
wybrany na oddanie łacińskiego rzeczownika regulus. Być może został on stworzony przez pisarza ad hoc (na zasadzie kalki wyrazu łacińskiego), ponieważ w całej staropolszczyźnie słowo krolik zostało w tym właśnie znaczeniu poświadczone wyłącznie w „Kazaniach augustiańskich” (pozostałe pojedyncze użycia tego wyrazu notowane w „Słowniku staropolskim” odnoszą się do zwierząt: królika, mysikrólika, bazyliszka, konika morskiego). Podobnie jak łaciński wyraz regulus pochodzi od rzeczownika rex (znaczenie wyrazu regulus podawane w słownikach to 'król małego kraju, książę'), tak i rzeczownik krolik został utworzony jako zdrobnienie od rzeczownika krol: mały król to krolik. To słowo doskonale oddaje sens wyrażony w łacińskim tekście oraz w objaśnieniach z komentarzy.

Warto zwrócić uwagę, że także i w tym miejscu autor dodatkowo odnosi objaśnienie do realiów ówczesnej Polski: ,niektore państwo, jako hodie staro[w]stwo albo wojewodztwo".

Kolejną różnicą między oboma tekstami, przywołaną na początku, jest język. W „Kazaniach augustiańskich” prawie wszystkie fragmenty perykopy biblijnej są wyrażone po łacinie lub dwujęzycznie (cztery łacińskie cytaty z Ewangelii, cztery cytaty dwujęzyczne, przy czym w trzech z nich przeważa polszczyzna, oraz dwa cytaty w całości po polsku). Trzeba powiedzieć, że w całym tym dwujęzycznym tekście to właśnie cytaty z Pisma Świętego dominują wśród większych partii łacińskich. Ta obserwacja jest nie bez znaczenia, jeśli myślimy o sposobie funkcjonowania tekstu biblijnego w tekście, który miał być docelowo realizowany po polsku. W kościele Pismo Święte, jak wiadomo, było czytane po łacinie. Łaciński tekst biblijny stał w centrum homilii - bardzo często głoszonej w języku wernakularnym - której funkcją było przede wszystkim skomentowanie i objaśnienie fragmentu Pisma. W RP z kolei wybór języka wernakularnego można wyjaśnić jedną z funkcji tekstu apokryficznego, polegającą na przybliżaniu ludziom treści związanych z życiem i działalnością Jezusa.

\section{Wnioski}

Analiza pogłębiła jeszcze wrażenie różnic między dwoma zaprezentowanymi tekstami. Prowadzi ona do wniosku, że w rozpoznanych przez M. Hoogvliet grupach/typach funkcjonowania Pisma Świętego mogło ono być traktowane w odmienny sposób, a różnice mogą być wielorakie: zarówno jeśli chodzi o język fragmentów ewangelicznych, sposób i zakres komentowania, wprowadzane zmiany, jak i o rolę tekstu biblijnego w kompozycji polskiego/polsko-łacińskiego tekstu. W RP interesująca mnie perykopa podana jest w kształcie zbliżonym do tekstu ewangelicznego i znajduje się w ciągu innych wydarzeń biblijnych. Dwa komentarze, które stanowią zasadnicze modyfikacje w stosunku do tekstu biblijnego, są wprowadzone do tekstu apokryfu i gramatycznie stanowią one apozycyjnie dosunięte zdania ${ }^{13}$. W Kaug tekst biblijny został z kolei poprzecinany

13 Tego typu konstrukcje, także w RP, I. Kwilecka uznaje za przejawy thumaczenia swobodnego Biblii. 
komentarzami o różnym charakterze, najczęściej następującymi po fragmencie z ewangelii i tworzącymi osobne, przeważnie rozbudowane całostki. Także funkcje uzupełnień są tylko w pewnej mierze wspólne. W RP objaśnieniu podlegają realia, które potencjalnie mogły być niezrozumiałe lub niejasne dla odbiorcy, w Kaug przybliżenie znaczenia obcych nazw jest zaś tylko jedną z funkcji komentarzy (obok wykładu teologicznego czy przetworzenia treści).

Jednocześnie perykopa i sposób jej potraktowania w omówionych tekstach mogą stanowić świadectwo swoistej jedności myśli i zanurzenia autorów we wspólnej tradycji komentowania Pisma Świętego. Pokazuje to fakt, że w dwóch tak różnych od siebie pod względem gatunkowym, funkcjonalnym i kulturowym zabytkach tę samą treść uznaje się za istotną do objaśnienia (co więcej, poświadczają to inne łacińskie teksty z epoki). Otwiera to jednak pytania znacznie ogólniejsze: o genezę objaśnień i możliwość wnioskowania na ich podstawie o autorach (nie każdy komentarz pochodzi od polskiego autora/pisarza, w wypadku tekstów wielowarstwowych genetycznie trudno jest także wskazać, na którym etapie powstawania dostępnej nam kopii został wprowadzony do tekstu). Ponadto rozbudowywanie tekstu biblijnego o objaśnienia było strategią pojawiającą się już na poziomie łaciny i stamtąd zostało zaczerpnięte do polskich tekstów średniowiecznych.

Wypada dopowiedzieć, że w samym RP, tekście bardzo obszernym i różnorodnym, nie wszystkie perykopy ewangeliczne są potraktowane w taki sposób jak ta, która została tu omówiona ${ }^{14}$. Wiele $\mathrm{z}$ nich jest obszernie komentowanych, i właśnie niektóre takie miejsca można uznać - co pokazywali w swoich pracach Tomasz Mika (2002) i Dorota Rojszczak-Robińska (2010) - za fragmenty przygotowane do wygłoszenia kazań. Rodzi to pytanie, czy między czterema wskazanymi przez M. Hoogvliet typami wykorzystania Biblii mogła istnieć grupa pośrednia ze względu na istnienie tekstów, które niełatwo zaklasyfikować do jednej z grup. Właśnie RP, przynależące do różnych światów (medytacyjnego i kaznodziejskiego), może być najlepszym przykładem tego, że granice między tymi typami są nieostre. Omawiane tu różnice między wykorzystaniem tej samej perykopy w RP i w Kaug w dużej mierze wynikają z funkcji, jaką miał pełnić dany tekst lub jego fragment. RP jako tekst wielowarstwowy kumuluje w sobie bardzo wiele różnych funkcji, dlatego to, co pokazałam jako charakterystyczne dla traktowania tekstu biblijnego na przykładzie jednej perykopy, nie może być w prosty sposób przeniesione na charakterystykę całego tekstu. Ta perykopa wydaje się pokazywać podstawową funkcję trzeciej grupy tekstów, wyróżnionej przez M. Hoogvliet (do której należą apokryfy), jaką jest zebranie w kolejności chronologicznej następujących po sobie wydarzeń biblijnych, i tym bardziej jest interesująca i ważna w kontekście podjętego tematu. Oba teksty oraz zasadnicze różnice między nimi paradoksalnie wskazują na wysokie prawdopodobieństwo istnienia niemożliwego do wskazania wprost w zachowanych polskich zabytkach całego spektrum funkcjonowania tekstu biblijnego, o którym pisała francuska badaczka. W przeanalizowanych tu sposobach przetworzenia i funkcjonowania perykopy

14 Różne sposoby językowego oddawania fragmentów Pisma św. w RP prezentuje M. Leńczuk (2016). 
można widzieć pojedyncze puzzle z całej niezachowanej do dzisiejszych czasów układanki, choć obraz tworzony z tego, co się zachowało, nigdy nie będzie do końca spójny, teksty te bowiem przynależą do różnych środowisk, powstały w różnym czasie, są świadectwem różnych procesów. To jednak tym bardziej umacnia w przekonaniu, że Biblia w polskim średniowieczu była przetwarzana i funkcjonowała w podobny sposób jak w całej ówczesnej Europie.

\section{Bibliografia}

Borowiec, K. (2015). Filologiczne wydanie „Rozmyślania przemyskiego” a czeski „Život Krista Pána”. LingVaria, 2, s. 179-192.

Brückner, A. (1901). Drobne zabytki polszczyzny średniowiecznej. Cz. 2. Kraków: Nakładem Akademii Umiejętności.

Dobrzeniecki, T. (1969). Łacińskie źródła „Rozmyślania przemyskiego”. W: J. Lewański (red.), Średniowiecze. Studia o kulturze. T. 4 (s. 196-521). Wrocław: Ossolineum.

Gesner, A. (2011). Glosy w „Rozmyślaniu przemyskim”. Wyniki analizy formalnej i perspektywy badań. Kwartalnik Językoznawczy, 3, s. 89-97.

Hoogvliet, M. (2013). The Medieval vernacular Bible in French as a flexible text: Selective and discontinuous reading practices. W: E. Poleg, L. Light (eds.), Form and function in the Late Medieval Bible (s. 283-306). Leiden: Brill.

Kossowska, M. (1968). Biblia w języku polskim. T. 1. Poznań: Księgarnia św. Wojciecha.

Kwilecka, I. (2003). Studia nad staropolskimi przekładami Biblii. Poznań: UAM, Wydział Teologiczny.

Leńczuk, M. (online). Staropolskie thumaczenia Nowego Testamentu. O projekcie. Pobrane z https://stnt.ijp. pan.pl/teksty/index/1 (20.07.2020).

Leńczuk, M. (2016). O sposobach tłumaczenia Nowego Testamentu w „Rozmyślaniu przemyskim”. W: J. Bartmiński, A. Timofiejew (red.), „Rozmyślanie przemyskie”. Świadectwo średniowiecznej kultury religijnej (s. 123-131). Przemyśl: Państwowa Wyższa Szkoła Wschodnioeuropejska.

Masłej, D. (2017). Zbiór glos czy tekst? „Kazania augustiańskie” jako problem edytorski i naukowy. W: K. Borowiec, D. Masłej, T. Mika, D. Rojszczak-Robińska (red.), Staropolskie Spotkania Językoznawcze 2: Jak wydawać teksty dawne? (s. 185-202). Poznań: Wydawnictwo Rys.

Masłej, D. (2020). Jak rodzit się średniowieczny tekst. Tak zwane „Kazania augustiańskie” w perspektywie historycznojęzykowej. Poznań: Poznańskie Studia Polonistyczne.

Masłej, D., Mika, T. (2020). Glosy jako integralny składnik średniowiecznego tekstu. W poszukiwaniu adekwatnych procedur badawczych. LingVaria, 1, s. 121-133.

Mazurkiewicz, R. (2007). Kilkanaście dalszych uzupełnień do źródeł „Rozmyślania przemyskiego”. W: R. Laskowski, R. Mazurkiewicz (red.), Amoenitates et lepores philologiae (s. 198-201). Kraków: Instytut Języka Polskiego PAN: Wydawnictwo Lexis.

Menache, S., Horowitz, J. (1996). Rhetoric and Its Practice in Medieval Sermons. Historical Reflections, 22(2), s. 321-350.

Mika, T. (2002). Maryja, Jezus, Bóg w „Rozmyślaniu przemyskim”. O nazywaniu osób. Poznań: Poznańskie Studia Polonistyczne.

Mika, T. (2015). Problemy z „Rozmyślaniem przemyskim”. Formułowanie sądów ogólnych a wielowarstwowość średniowiecznego tekstu. LingVaria, $n r$ specjalny, s. 87-104.

Mika, T., Rojszczak-Robińska, D. (2016). Kanon wiedzy o „Rozmyślaniu przemyskim”. W: J. Bartmiński, A. Timofiejew (red.), ,Rozmyślanie przemyskie”. Świadectwo średniowiecznej kultury religijnej (s. 13-24). Przemyśl: Państwowa Wyższa Szkoła Wschodnioeuropejska. 
Pietkiewicz, R. (2013). Tradycja rękopiśmienna polskich przekładów biblijnych od XIII do XVI wieku. Wroctawski Przeglad Teologiczny, 21(2), s. 29-50.

Pietkiewicz, R. (2016). Biblia Polonorum. Historia Biblii w języku polskim, T. 1. Poznań: Pallotinum.

Poleg, E., Light, L. (2013). Introduction. W: E. Poleg, L. Light (eds.), Form and function in the Late Medieval Bible (s. 1-7). Leiden: Brill.

Rojszczak-Robińska, D. (2010). Spowiedź Judasza, czyli o nieznanym staropolskim kazaniu ukrytym w tekście apokryfu. W: M. Olczyk, W. Radecki (red.), Memoriale Domini. Księga pamiatkowa dedykowana księdzu profesorowi Jerzemu Stefańskiemu w 70. rocznicę urodzin (s. 529-545). Gniezno: Prymasowskie Wyższe Seminarium Duchowne.

Rojszczak-Robińska, D. (2012). Jak pisano „,Rozmyślanie przemyskie”. Poznań: Wydawnictwo Rys.

Rojszczak-Robińska, D. (2015). Łacińskie źródła „Rozmyślania przemyskiego”. Pytania, problemy, perspektywy. W: T. Mika, D. Rojszczak-Robińska, O. Stramczewska (red.), Staropolskie Spotkanie Językoznawcze 1: Jak badać teksty staropolskie (s. 135-172). Poznań: Wydawnictwo Rys.

Smalley, B. (1978). The study of the Bible in the Middle Ages. Notre Dame: University of Notre Dame Press.

Stallybrass, P. (2002). Books and scrolls: Navigating the Bible. W: J. Andersen, E. Sauer (eds.), Books and readers in Early Modern England: Material studies (s. 42-79). Philadelphia: University of Pennsylvania Press.

Twardzik, W. (1994). Glosy w „Rozmyślaniu przemyskim”. Teksty Drugie, 2, s. 156-165.

Twardzik, W., Keller, F. (wyd./Hrsg.) (1998-2004). „Rozmyślanie przemyskie”. Transliteracja, transkrypcja, podstawa łacińska, niemiecki przektad/Transliteration, Transkription, lateinische Vorlagen, deutsche Übersetzung. T./Bd. 1-3. Freiburg: U.W. Weiher.

Wanicowa, Z. (2010). Mechanizm błędów translacyjnych w „Biblii Królowej Zofii” a spór o podstawę jej przekładu. Językoznawstwo. Współczesne badania, problemy i analizy językoznawcze, 4, s. 13-35.

Wenzel, S. (2005). The arts of preaching. W: A. Minnis, I. Johnson (eds.), The Cambridge history of literary criticism. Vol. 2: The Middle Ages (s. 84-96). Cambridge: Cambridge University Press.

Wydra, W., Rzepka, W.R. (2004). Chrestomatia staropolska. Teksty do roku 1543, wyd. 3. Wrocław: Zakład Narodowy im. Ossolińskich.

Zajchowska-Bołtromiuk, A. (2018). Przeszłość w zbiorach kazań modelowych de tempore i de sanctis mistrzów Uniwersytetu Krakowskiego w XV wieku. W: J. Banaszkiewicz, A. Dąbrówka, P. Węcowski (red.), Przeszłość w kulturze średniowiecznej Polski, T. 1 (s. 607-655). Warszawa: Instytut Historii PAN-Neriton.

\section{STRESZCZENIE}

Słowa kluczowe: komentarz biblijny, „Rozmyślanie przemyskie”, „Kazania augustiańskie”, Biblia w średniowieczu, przekład Biblii.

Celem artykułu jest odniesienie zaproponowanego przez Margriet Hoogvliet katalogu najbardziej typowych form funkcjonowania i obiegu tekstu biblijnego w średniowieczu do zachowanego materiału staropolskiego oraz próba odpowiedzi na pytanie, czy sposób traktowania fragmentów Pisma św. w tekstach z różnych grup jest odmienny. Aby to uczynić, porównano sposoby wykorzystania i komentowania perykopy biblijnej o uzdrowieniu syna dworzanina w dwóch polskich tekstach: „Kazaniach augustiańskich”, pochodzących z polsko-łacińskiej kolekcji materiałów kaznodziejskich, oraz w „Rozmyślaniu przemyskim”, najobszerniejszym staropolskim tekście apokryficznym. W artykule przedstawiono analizę różnic między thumaczeniem i objaśnieniem tej perykopy w obu tekstach. Analiza ta prowadzi do wniosku, że sposób traktowania fragmentów z Pisma św. w obu tekstach jest różny, różnice zaś wynikają przede wszystkim z funkcji obu tekstów i celu przyświecającego pisarzowi. Ponadto można sądzić, że w Polsce istniały wszystkie rozpoznane przez badaczy zachodnich formy, mimo że zachowały się tylko ślady - ale bardzo zróżnicowane - ich obecności. 


\section{SUMMARY}

Use of the Bible in apocryphal texts and preaching materials on the basis of Old Polish translations of the pericope on the healing of the courtier's son

Keywords: biblical commentary, "Rozmyślanie przemyskie", "Kazania augustiańskie", the Bible in the Middle Ages, Biblical translation.

The aim of the paper is to apply the catalog of the most characteristic forms in which the Biblical text circulated during this period, recognized by Margriet Hoogvliet, to the Old Polish sources and to answer the question about possible differences in using the Bible in texts from divergent groups recognized by Hoogvliet. The article analyses two Old Polish texts referring to the same biblical pericope in Latin, namely, the healing of the courtier's son (John 4: 45-54). One of the texts comes from a Polish-Latin collection of preaching materials, known as "Kazania augustiańskie", dated to the turn of the $15^{\text {th }}$ and $16^{\text {th }}$ centuries, while the second one is included in "Rozmyślanie przemyskie", the most extensive Polish Apocrypha, dated to well before the beginning of the $16^{\text {th }}$ century. In this paper I discuss the differences between the ways in which this pericope had been translated and interpreted in these two texts. The analysis lead to the conclusion that the ways of using the fragments of the Bible are different in texts from both groups. The reasons of such differences are mostly the functions of respective texts, and their intended use. Moreover, it can be assumed that in medieval Poland there were all the forms recognized by Western researchers, even though only traces - but very different from each other - of their presence have preserved. 